\title{
PEMETAAN ANIMO PESERTA DIDIK SMK NEGERI PRODI KEAHLIAN TEKNIK KOMPUTER DAN INFORMATIKA SE-KOTA MALANG UNTUK MELANJUTKAN STUDI KE PERGURUAN TINGGI DENGAN PRODI YANG SEBIDANG
}

\author{
Anggi Kusuma Irawan ${ }^{1}$, Tri Atmadji Sutikno dan I Made Wirawan ${ }^{2}$ \\ Jurusan Teknik Elektro, Universitas Negeri Malang \\ Malang, Indonesia \\ e-mail: anggikusuma37@gmail.com, tri.atmadji.ft@um.ac.id, made.wirawan.ft@um.ac.id
}

\begin{abstract}
Abstrak
Lulusan Sekolah Menengah Kejuruan (SMK) bisa melanjutkan ke perguruan tinggi tidak hanya lulusan Sekolah Menengah Atas (SMA) saja. Peserta didik SMK dapat mengembangkan potensi di perguruan tinggi dengan prodi yang sesuai dengan jurusan yang digeluti untuk menjadi teknisi yang handal dibidangnya. Dalam penelitian ini terdapat seberapa besar animo peserta didik SMK prodi keahlian teknik komputer dan informatika untuk melanjutkan studi ke perguruan tinggi dengan prodi yang sebidang serta faktor internal dan eksternal yang mempengaruhinya. Penelitian ini dilakukan pada peserta didik SMK Negeri prodi keahlian teknik komputer dan informatika kelas 12 tahun ajaran 2018/2019 Se-Kota Malang dengan jumlah sampel 559 peserta didik dan menggunakan analisis statistik deskriptif. Hasil analis yang dilakukan berhasil mendapatkan $72,63 \%$ peserta didik ingin melanjutkan ke perguruan tinggi dan 27,37\% memilih untuk tidak melanjutkan. Kecenderungan animo peserta didik yang ingin melanjutkan perguruan tinggi berada pada kategori tinggi yaitu $56,15 \%$. Presentase skor faktor yang mempengaruhi yaitu, faktor dari dalam diri sendiri $82,53 \%$ berada pada kategori sangat tinggi, faktor lingkungan keluarga $79,58 \%$ berada pada kategori tinggi, dan faktor lingkungan sekolah $74,62 \%$ berada pada kategori tinggi. Kemudian sebanyak $70,93 \%$ peserta didik memilih prodi yang sebidang. Penelitian ini berhasil mengungkap: (1) Kecenderungan animo berada pada kategori tinggi; (2) presentase skor faktor dalam diri sendiri lebih besar; (3) sebagian besar memilih prodi yang sebidang; (4) prodi teknik informatika paling banyak diminati.
\end{abstract}

Kata kunci: animo, faktor mempengaruhi animo.

\begin{abstract}
Graduates of Vocational High School also could continue to college, not only graduates of Senior High School. Students of Vocational High School could develop their potentials in college by choosing the right major that suited their majors that they had been learned to be capable technicians in their own fields. In this research, there could be found how much Vocational High School students of Computer and Informatics Engineering were interested to continue their studies to college with the same major and internal and external factors that affected it. This research was done to Public Vocational High School students with Computer and Informatics Engineering as their major of grade 12 and year 2018/2019 in Malang City with the total of sample was 559 students and using desctiptive statistical analysis. The result of analysis that was done showed that $72.63 \%$ students wanted to continue to college and $27.37 \%$ chose not to continue to college. The interests tendency of students who wanted to continue to college was in high level, which was $56.15 \%$. The percentage of score of the factors that affected it were $82.53 \%$ internal factor which was in very high level, $79.58 \%$ family environmental factor which was in high level, and $74.62 \%$ school environmental factor which was in high level. Then, $70.93 \%$ students chose major that had the same field. This research discoveried: (1) intererests tendency was in high
\end{abstract}


level; (2) percentage of score of internal factor was biger than any other factors; (3) most sfudents chose major that had the same field; (4) the major that most chosen by students was Informatics Engineering.

Keywords : interest, factors affected the interests

\section{PENDAHULUAN}

Dalam rangka mewujudkan tujuan pendidikan yang tertuang dalam pembukaan UUD 1945 yaitu "mencerdaskan kehidupan bangsa" maka, mutu pendidikan di Indonesia perlu selalu ditingkatkan. Sebab pendidikan merupakan wahana atau salah satu instrumen yang digunakan bukan saja untuk membebaskan manusia dari keterbelakangan, melainkan juga dari kebodohan dan kemiskinan. Pendidikan diyakini mampu menanamkan kapasitas baru bagi semua orang untuk mempelajari pengetahuan dan keterampilan baru sehingga dapat diperoleh manusia produktif. Di sisi lain, pendidikan di percaya sebagai wahana perluasan akses. Semakin ketatnya persaingan di era globalisasi kemajuan teknologi dan tuntutan persaingan di dunia kerja, sangat dibutuhkan sumber daya manusia yang mampu membangun dirinya sendiri serta bersama-sama bertanggung jawab atas pembangunan bangsa.

Masalah kemiskinan rakyat tidak lepas dari sistem pendidikan yang ada, dengan demikian pemerintah mencoba membuka sistem pendidikan yang mengedepankan keahlian dan kreatifitas masyarakat. Disebut Sekolah Menengah Kejuruan (SMK), merupakan jenjang pendidikan menengah yang mengutamakan pengembangan keterampilan peserta didik untuk melaksanakan jenis pekerjaan tertentu. SMK bertujuan untuk mempersiapkan peserta didik agar memiliki keterampilan dan siap terjun ke dunia kerja. Terdapat berberapa jurusan yang kesemuanya mengutamakan keahlian serta kreatifitas yang mampu menciptakan lapangan kerja sendiri ataupun bekerja di perusahaan swasta bahkan BUMN.

Meski sekolah menengah kejuruan (SMK) merupakan sekolah yang beriorentasi pada dunia kerja dan salah satu tujuanya memberikan bekal kepada siswa untuk siap masuk dunia kerja, sebagai tenaga kerja yang terampil tingkat menengah sesuai dengan persyaratan yang dituntut oleh dunia kerja. Kegiatan belajar mengajar pada sekolah menengah kejuruan diarahkan untuk membentuk kemampuan siswa dalam mengembangkan perolehan belajarnya baik pada aspek pengetahuan, keterampilan dan tata nilai maupun pada aspek sikap guna menunjang pengembangan potensinya (kep. Mendikbud No. 080/U/1993). Bagi siswa SMK hal ini juga bisa merupakan alasan minat siswa untuk tetap melanjutkan studi ke jenjang pendidikan yang lebih tinggi yaitu perguruan tinggi.

Perguruan tinggi adalah suatu
lembaga pendidikan menyelenggarakan pendidikan dan berbagai macam keahlian, misalnya : bidang pendidikan teknik, ekonomi, hukum, psikologi, kesehatan dan lain-lain. Sesuai Undang-Undang No. 20 tahun 2003 menetapkan perguruan tinggi berupa Akademik, Politeknik, Sekolah Tinggi Institut atau Universitas yang ditetapkan pemerintah. Hal ini juga bisa melihat PP No. 56 Tahun 1998 lulusan SMK juga dapat melanjutkan pendidikan kejenjang perguruan yang lebih tinggi. Harapannya mereka bisa melanjutkan ke perguruan tinggi dengan bidang yang sesuai dengan jurusan yang sudah mereka geluti. Dengan melanjutkan ke perguruan tinggi mereka bisa lebih mengembangkan potensi diri dan menjadi teknisi yang handal dibidangnya.

Peserta didik SMK prodi keahlian teknik komputer dan informatika harapannya akan melanjutkan studi di perguruan tinggi dengan prodi yang sesuai dengan bidangnya. Misalnya saja prodi teknik informatika, ilmu komputer, sistem informasi, pendidikan teknik informatika, dan lain sebagainya. Berdasarkan data dari badan statistik Universitas Negeri Malang dalam tiga tahun terakhir peminat prodi pendidikan teknik informatika terus mengalami penurunan, tahun 2016 terdapat 1938 peminat, kemudian tahun 2017 menurun jadi 1792 peminat, dan terakhir tahun 2018 menurun menjadi 1619 peminat. Prodi teknik informatika memiliki statistik yang berbeda, 
tahun 2016 terdapat 3962 peminat, tahun 2017 menurun menjadi 3634 peminat, lalu tahun 2018 meningkat jadi 4099 peminat. Prodi teknik informatika lebih banyak diminati.

Berdasarkan data yang didapat dari kabag akademik Universitas Negeri Malang, pada tahun 2017 prodi pendidikan informatika dan teknik informatika menerima 196 mahasiswa, 139 mahasiswa lulusan SMA (71\%) dan 57 mahasiswa lulusan SMK (29\%). Tahun 2018 menerima 185 mahasiswa, 139 mahasiswa lulusan SMA $(75 \%)$ dan 46 mahasiswa lulusan SMK (25\%). Jadi 2 tahun terakhir jumlah siswa SMK yang di terima menurun $4 \%$. Hal ini bisa disebabkan oleh jumlah animo siswa SMK yang ingin melanjutkan ke perguruan tinggi menurun.

Animo adalah "hasrat dan keinginan yang kuat untuk berbuat, melakukan atau mengikuti sesuatu" (Kamus Besar Bahasa Indonesia, 2006: 53). Animo bagi sebagian masyarakat lebih banyak disamakan arti dan pengertiannya dengan kata minat. Menurut Syah (2005: 136) [14] mengemukakan bahwa, "Minat adalah kecenderungan dan kegairahan yang tinggi atau keinginan besar terhadap sesuatu". Sedangkan menurut Menurut Sardiman (2011: 76) [8], "Minat diartikan sebagai kecenderungan jiwa seseorang kepada sesuatu (biasanya disertai dengan perasaan senang), karena itu merasa ada kepentingan dengan sesuatu itu".

Faktor-faktor yang dapat mempengaruhi minat siswa melanjutkan pendidikan di perguruan tinggi dapat diklasifikasikan dalam dua kategori besar yaitu faktor internal dan faktor eksternal (Suhirno, 2011:15) [12]. Faktor internal adalah faktor yang ada dalam diri individu. Kraap (2007) [6] bahwa kelas sosial, karakteristik individu seperti kecerdasan mempengaruhi minat seseorang dalam proses dan hasil belajar. Menurut Santoso (dalam Wahyudi, 2006:18) [15] cita-cita dapat mempengaruhi tumbuh kembangnya minat. Menurut Dalyono (1994:55) [3] timbulnya minat disebabkan berbagai hal, antara lain karena keinginan yang kuat untuk menaikan martabat atau memperoleh pekerjaan yang baik serta ingin hidup senang dan bahagia Salah satu yang mempengaruhi minat adalah motivasi (Suprapto, 2007:12) [13]. Berdasarkan pendapat-pendapat di atas, faktor internal terdiri dari motivasi, cita-cita, dan keinginan. Faktor eksternal adalah faktor yang ada di luar individu. Menurut suprapto (2007:10) [13] "faktor lingkungan adalah faktor yang dapat memunculkan minat yang berasal dari keadaan sekitar seperti: lingkungan keluarga, lingkungan sekolah". Jadi terdapat faktor lingkungan keluarga dan lingkungan sekolah yang mempengaruhi minat peserta didik.

\section{METODE}

Penelitian ini termasuk jenis penelitian kuantitatif dengan metode deskriptif, artinya mendeskripsikan secara sistematis, faktual, dan akurat sesuai situasi, kondisi atau bidang interest tertentu. Penelitian ini menggambarkan kecenderungan animo peserta didik SMK prodi keahlian teknik komputer dan informatika untuk melanjutkan ke perguruan tinggi, faktor yang mempengaruhinya, serta pilihan mereka untuk melanjutkan ke prodi yang sebidang dengan jurusan yang digelutinya atau memilih prodi yang lain.

Populasi dalam penelitian ini adalah peserta didik SMK Negeri prodi keahlian teknik komputer dan informatika kelas 12 tahun ajaran 2018/2019 Se-Kota Malang dengan jumlah populasi 2227 peserta didik. Kemudian pengambilan sampel dengan mengalikan jumlah populasi dengan koefisien menurut Arikunto yaitu 25\% maka hasilnya menjadi 557 peserta didik. Pembagian sampel pada tiap sekolah menggunakan teknik proportional random sampling.

Teknik pengumpulan data penelitian menggunakan instrumen. Instrumen penelitian yang digunakan yaitu berupa kuisioner/angket yang diadaptasikan dengan skala likert. Angket terdiri dari pernyataan yang dikembangkan dari indikator kisi-kisi instrumen, penyusunan kisi-kisi instrumen berdasarkan teori-teori yang telah dipaparkan pada kajian teori. Berdasarkan tujuan penelitian tersebut, maka analisa data yang digunakan yaitu analisis statistik deskriptif. 


\section{HASIL DAN PEMBAHASAN}

A. Animo Peserta Didik SMK Negeri Prodi Keahlian Teknik Komputer dan Informatika Se-Kota Malang untuk Melanjutkan ke Perguruan Tinggi

Suciani \& Setyadin (2008:55) [10] mengemukakan bahawa "Animo peserta didik adalah hasrat dan keinginan yang kuat dari diri peserta didik untuk melakukan sesuatu demi tercapainya keinginan dan cita-cita yang diinginkannya". Dalam penelitian ini animo untuk melanjutkan ke perguruan tinggi adalah keinginan yang kuat dari peserta didik untuk melanjutkan ke perguruan tinggi. Diperoleh data Animo Peserta Didik SMK Negeri Prodi Keahlian Teknik Komputer dan Informatika Se-Kota Malang untuk Melanjutkan ke Perguruan Tinggi yang dapat dilihat pada gambar 1 dan 2

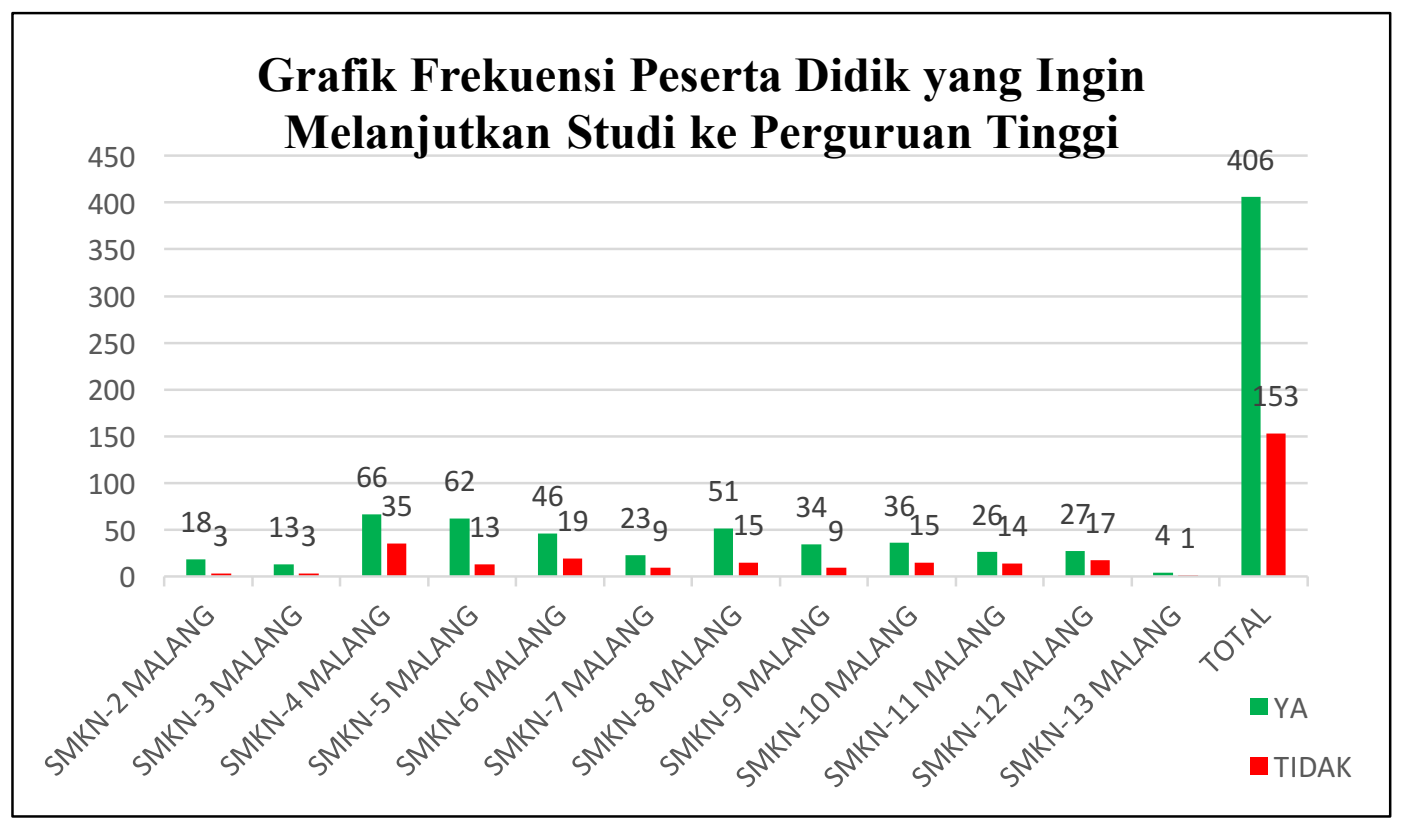

Gambar 1 Frekuensi Peserta Didik Yang Ingin Melanjutkan Ke Perguruan Tinggi

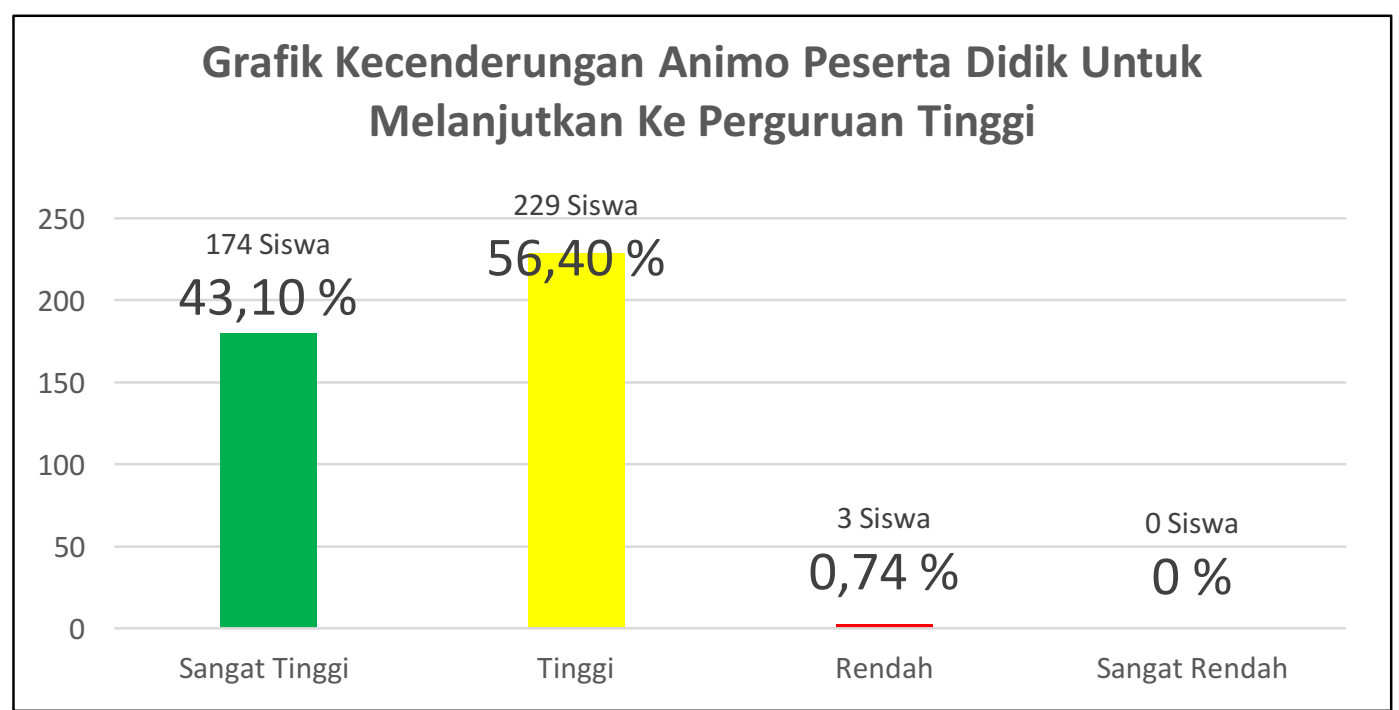

Gambar 2 Tingkat Kecenderungan Animo Peserta Didik Untuk Melanjutkan Ke Perguruan

Tinggi 
Gambar 1 menjelaskan frekuensi peserta didik yang ingin melanjutkan ke perguruan tinggi dan yang tidak ingin melanjutkan ke perguruan tinggi dari tiap sekolah. Dari grafik tersebut terlihat total peserta didik yang mengatakan "Ya" sebanyak 406 peserta didik $(72,63 \%)$ dan yang mengatakan "Tidak" sebanyak 153 peserta didik $(27,37 \%)$.

Gambar 2 menjelaskan tingkat kecenderungan animo peserta didik yang ingin melanjutkan ke perguruan tinggi. Dari 406 responden yang menjawab "Ya" sebanyak 174 siswa $(43,10 \%)$ berada pada kategori animo sangat tinggi, 229 siswa $(56,40 \%)$ pada kategori tinggi, 3 siswa $(0,74 \%)$ kategori rendah, dan tidak ada siswa $(0 \%)$ pada kategori animo sangat rendah.

Gambar 1 dan Gambar 2 menunjukkan jumlah frekuensi peserta didik yang ingin melanjutkan ke perguruan tinggi lebih banyak dari frekuensi peserta didik yang tidak ingin melanjutkan ke perguruan tinggi. Kemudian sebagian besar peserta didik SMK Negeri prodi keahlian teknik komputer dan informatika Se-Kota memiliki Animo yang tinggi untuk melanjutkan studi ke perguruan tinggi, yakni sebesar 229 siswa $(56,40 \%)$ dengan persentase skor animo $79,85 \%$, Sesuai dengan penelitian Lea (2003) [7] menunjukkan bahwa minat belajar memiliki pengaruh yang signifikan dalam belajar di perguruan tinggi. Hasil ini sesuai dengan penelitian Suhirno (2011:56) [12] menyatakan bahwa minat masuk perguruan tinggi bagi siswa kelas XII Program Keahlian Teknik Ototronik di SMK Negeri 1 Seyegan tergolong kategori tinggi yaitu dengan rata-rata $69,24 \%$. Serta penelitian. Dalam hal ini dapat dikatakan siswa masih memiliki niat yang tinggi untuk melanjutkan studi ke perguruan tinggi.

\section{B. Faktor Mempengaruhi Animo} Melanjutkan Studi Ke Perguruan Tinggi

\section{Faktor Diri Sendiri}

Ditinjau dari tiap-tiap indikator dari dalam diri sendiri yang mempengaruhi animo peserta didik SMK Negeri Prodi Keahlian Teknik Komputer dan Informatika Se-Kota Malang yang ingin melanjutkan ke perguruan tinggi:

\subsection{Motivasi}

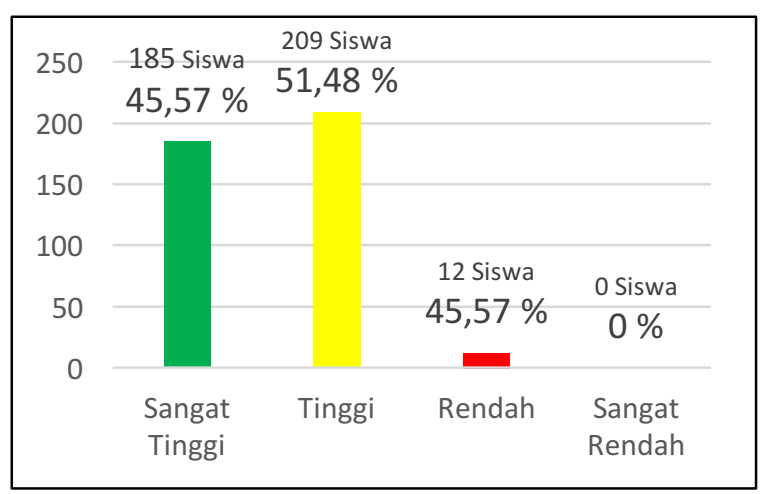

Gambar 3 Motivasi

Gambar 3 menjelaskan indikator motivasi dari dalam diri sendiri yaitu, sebanyak 185 siswa $(49,26 \%)$ berada pada kategori sangat tinggi, 198 siswa $(48,77 \%)$ pada kategori tinggi, 8 siswa $(1,97 \%)$ kategori rendah, dan tidak ada siswa $(0 \%)$ pada kategori sangat rendah.

\subsection{Cita-cita}

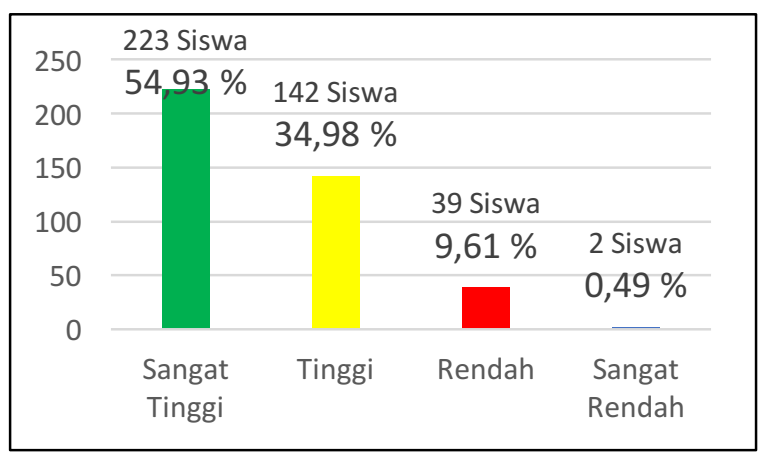

Gambar 4 Cita-cita

Gambar 4 menjelaskan indikator cita-cita dari dalam diri sendiri yaitu, sebanyak 223 siswa $(54,93 \%)$ berada pada kategori sangat tinggi, 143 siswa $(34,98 \%)$ pada kategori tinggi, 39 siswa $(9,61 \%)$ kategori rendah, dan 2 siswa $(0.49 \%)$ pada kategori sangat rendah. 
1.3 Keinginan

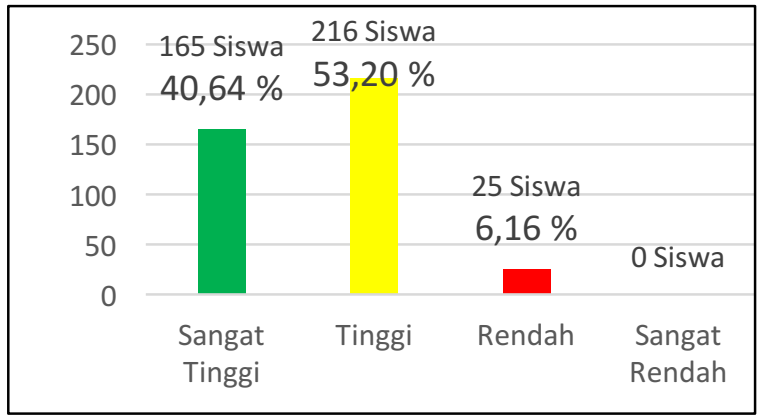

Gambar 5 Keinginan

Gambar 5 menjelaskan indikator keinginan dari dalam diri sendiri yaitu, sebanyak 165 siswa $(40,64 \%)$ berada pada kategori sangat tinggi, 216 siswa $(53,20 \%)$ pada kategori tinggi, 25 siswa $(6,16 \%)$ kategori rendah, dan tidak ada siswa (0\%) pada kategori sangat rendah.

sendiri:

Hasil keseluruhan variabel faktor diri

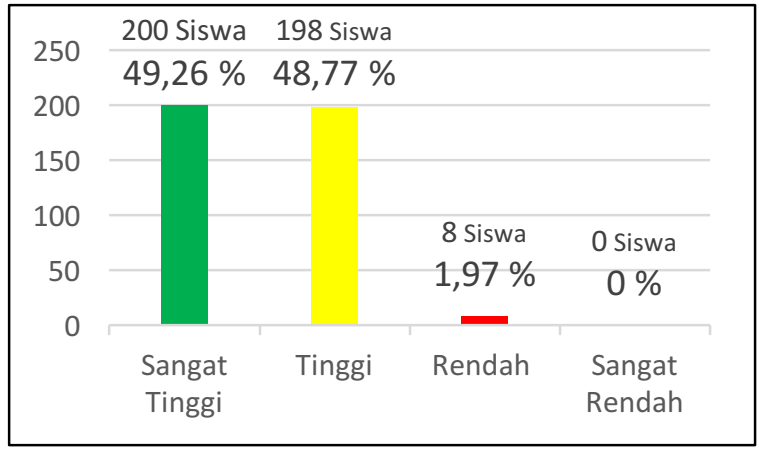

Gambar 6 Faktor Diri Sendiri

Berdasarkan hasil penelitian pada Gambar 6 sebanyak 200 siswa $(49,26 \%)$ berada pada kategori sangat tinggi, 198 siswa $(48,77 \%)$ pada kategori tinggi, 8 siswa $(1,97 \%)$ kategori rendah, dan tidak ada siswa $(0 \%)$ pada kategori sangat rendah. Hal ini menunjukkan faktor diri sendiri berada pada kategori sangat tinggi yakni 200 siswa $(49,26 \%)$ dengan persentase skor $82,53 \%$.

Persentase skor masing-masing subvariabel dalam faktor diri sendiri sebagai berikut: motivasi sebesar $80,36 \%$ berada pada kategori tinggi, cita-cita sebesar $84,33 \%$ pada kategori sangat tinggi, dan keinginan sebesar $82,73 \%$ pada kategori tinggi. Pada faktor dalam diri sendiri subvariabel cita-cita mempunyai persentase skor terbesar $(84,58 \%)$, untuk item yang mempunyai persentase terbesar terletak pada butir 27 sebesar $85,04 \%$ yang menyatakan bahwa "saya ingin menjadi seorang yang ahli di bidang saya". Sedangkan subvariabel motivasi mempunyai persentase skor terkecil $(80,60 \%)$, untuk item yang mempunyai ratarata terkecil teletak pada butir 22 sebesar $73,83 \%$ yang menyatakan bahwa "bila dilihat dari prestasi saya selama ini, saya memungkinkan untuk diterima di perguruan tinggi", Sesuai dengan pendapat Santoso (dalam Wahyudi, 2006:18) [15] bahwa "citacita dapat mempengaruhi tumbuh kembangnya minat". Hasil ini juga sesuai dengan penelitian Alfurqon (2012:82) [2] menyatakan bahwa siswa pada umumnya memiliki kemauan untuk melanjutkan studi ke perguruan tinggi yang dikarenakan adanya cita-cita tertentu yang ingin dicapai.

\section{Faktor Lingkungan Keluarga}

Ditinjau dari tiap-tiap indikator dari lingkungan keluarga yang mempengaruhi animo peserta didik SMK Negeri Prodi Keahlian Teknik Komputer dan Informatika Se-Kota Malang melanjutkan ke perguruan tinggi:

\subsection{Pendidikan Keluarga}

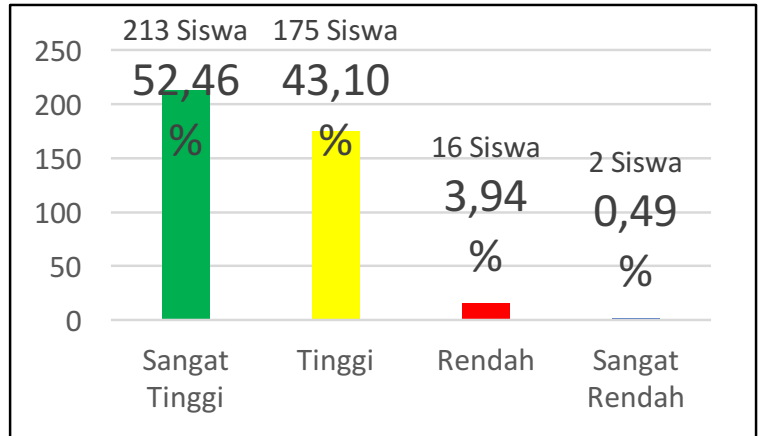

Gambar 7 Pendidikan Keluarga

Gambar 7 menjelaskan indikator pendidikan keluarga dari lingkungan keluarga yaitu, sebanyak 213 siswa $(52,46 \%)$ berada pada kategori sangat tinggi, 175 siswa $(43,10 \%)$ pada kategori tinggi, 16 siswa $(3,94 \%)$ kategori rendah, dan 2 siswa $(0,49 \%)$ pada kategori sangat rendah 


\subsection{Ekonomi Keluarga}

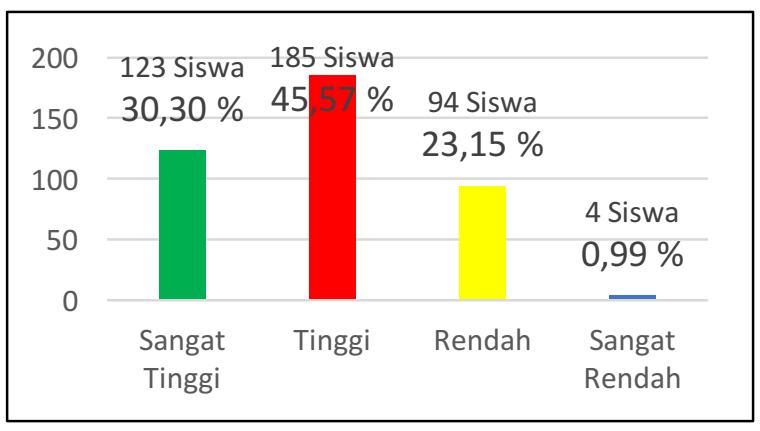

Gambar 8 Ekonomi Keluarga

Gambar 8 menjelaskan indikator ekonomi keluarga dari lingkungan keluarga yaitu, sebanyak 123 siswa $(30,30 \%)$ berada pada kategori sangat tinggi, 185 siswa $(45,57 \%)$ pada kategori tinggi, 94 siswa $(23,15 \%)$ kategori rendah, dan 4 siswa $(0,99 \%)$ pada kategori sangat rendah.

Hasil keseluruhan variabel lingkungan keluarga:

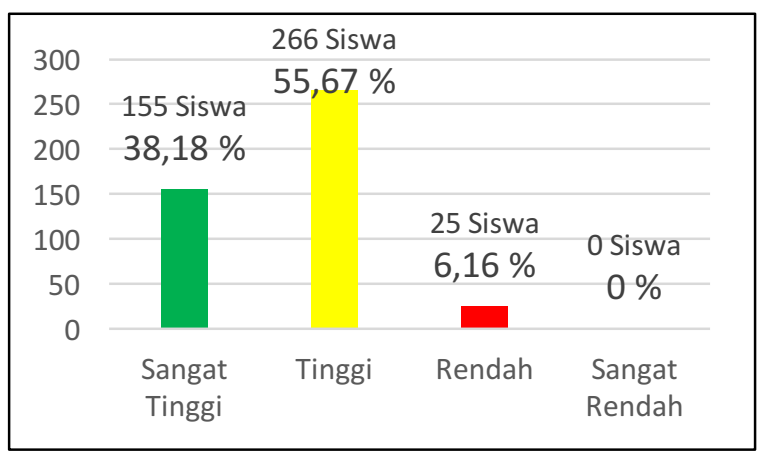

Gambar 9 Faktor Lingkungan Keluarga

Berdasarkan hasil penelitian pada Gambar 9 sebanyak 155 siswa $(38,18 \%)$ berada pada kategori sangat tinggi, 226 siswa $(55,67 \%)$ pada kategori tinggi, 25 siswa $(6,16 \%)$ kategori rendah, dan tidak ada siswa $(0 \%)$ pada kategori sangat rendah. Hal ini menunjukkan faktor lingkungan keluarga berada pada kategori tinggi yakni 226 siswa $(55,67 \%)$ dengan persentase skor $79,85 \%$.

Persentase skor masing-masing subvariabel dalam faktor lingkungan keluarga sebagai berikut: pendidikan keluarga sebesar $82,31 \%$ berada pada kategori sangat tinggi, dan ekonomi keluarga sebesar $75,71 \%$ pada kategori tinggi. Pada lingkungan keluarga subvariabel pendidikan keluarga mempunyai persentase skor terbesar $(82,31 \%)$, untuk item yang mempunyai persentase terbesar terletak pada butir 32 sebesar $84,24 \%$ yang menyatakan bahwa "dalam memilih jurusan di perguruan tinggi orang tua memberikan saya kebebasan". Sedangkan subvariabel ekonomi keluarga mempunyai persentase skor terkecil $(75,71 \%)$, untuk item yang mempunyai ratarata terkecil teletak pada butir 34 sebesar $68,29 \%$ yang menyatakan bahwa "biaya kuliah di perguruan tinggi masih bisa dijangkau keluarga saya". Hasil ini sesuai dengan penelitian Alfurqon (2012:83) [2] menyatakan bahwa kondisi keluarga yang kondusif dan adanya dukungan dari orang tua untuk melanjutkan studi ke perguruan tinggi dapat mengatasi pengaruh negatif dari keadaan sosial ekonomi orang tua yang kurang baik.

Keluarga adalah salah satu yang utama dalam perkembangan pendidikan seorang anak dalam melanjutkan studinya. Dalam penelitian Wilcox (2005) [16] menunjukkan bahwa dukungan social dari keluarga baik dalam aspek material memberikan kepercayaan diri siswa dalam hal akademis. Terdapat dua indikator yaitu pendidikan keluarga dan ekonomi keluarga. Pendidikan keluarga menjadi indikator yang paling berpengaruh. Sesuai dengan hasil penelitian pernyataan kebebasan memilih jurusan memiliki persentase skor tertinggi, hal ini cocok dengan pendapat Ihsan (2003:05) [4] yaitu "Pendidikan keluarga merupakan suatu pengarahan dan bimbingan yang diberikan kepada anak dalam pertumbuhannya". serta pendapat Marsiyati (2005:51) "Democratic parental sttyle yaitu pola asuh yang menitik beratkan pada tujuan dan mengizinkan anak bersifat individualis" yang berarti orang tua melakukan pengarahan dan bimbingan kepada anaknya kemudian keputusan tetap ada pada anak itu sendiri. Kemudian ekonomi keluarga dapat mempengaruhi keputusan seorang anak. Dalam penelitian ini pernyataan biaya kuliah yang yang masih bisa dijangkau memiliki presentase skor yang terkecil yang artinya biaya kuliah masih sulit dijangkau bagi sebagian siswa yang memiliki ekonomi rendah. sesuai dengan penelitian Ajake (2013) [1] dalam jurnalnya 
mengungkapkan bahwa status sosio ekonomi keluarga berpengaruh terhadap pendidikan seorang anak. Serta penelitian Kainuwa (2013) [5] menunjukan pendapatan orang tua berpengaruh secara signifikan terhadap pendidikan anak - anaknya. Keinginan untuk meningkatkan ekomoni keluarga menjadi salah satu alasan mereka untuk melanjutkan ke perguran tinggi.

\section{Faktor Lingkungan Sekolah}

Ditinjau dari tiap-tiap indikator dari lingkungan sekolah yang mempengaruhi animo peserta didik SMK Negeri Prodi Keahlian Teknik Komputer dan Informatika Se-Kota Malang melanjutkan ke perguruan tinggi:

\subsection{Alumni Sekolah}

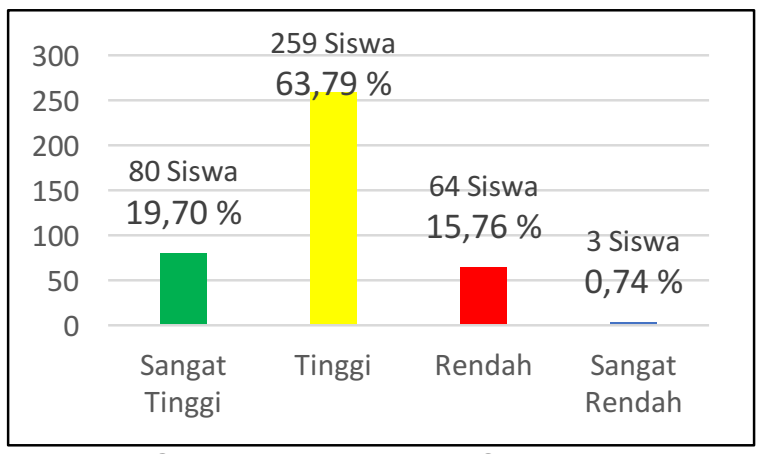

Gambar 10 Alumni Sekolah

Gambar 10 menjelaskan indikator alumni sekolah dari lingkungan sekolah yaitu, sebanyak 80 siswa $(19,70 \%)$ berada pada kategori sangat tinggi, 259 siswa $(63,79 \%)$ pada kategori tinggi, 64 siswa $(15,76 \%)$ kategori rendah, dan 3 siswa $(0,74 \%)$ pada kategori sangat rendah.

\subsection{Teman}

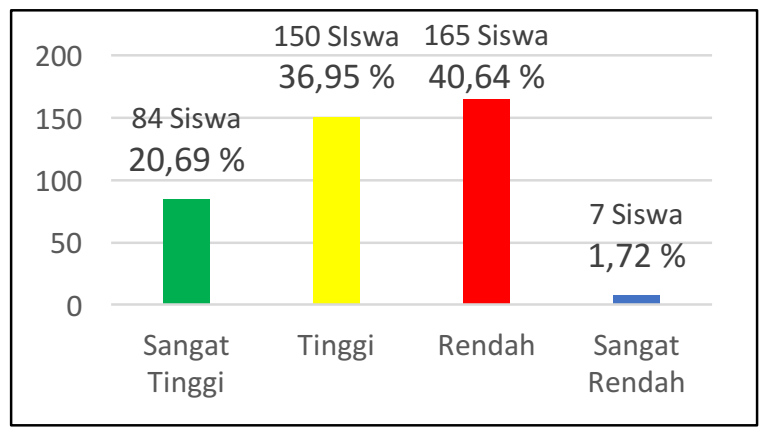

Gambar 11 Teman
Gambar 11 menjelaskan indikator teman dari lingkungan sekolah yaitu, sebanyak 84 siswa $(20,69 \%)$ berada pada kategori sangat tinggi, 150 siswa $(36,95 \%)$ pada kategori tinggi, 165 siswa $(40,64 \%)$ kategori rendah, dan 7 siswa $(1,72 \%)$ pada kategori sangat rendah.

\subsection{Guru}

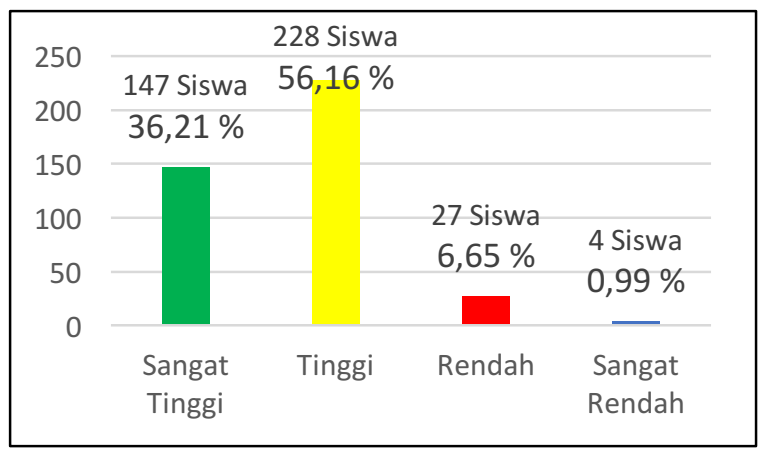

Gambar 12 Guru

Gambar 12 menjelaskan indikator guru dari lingkungan sekolah yaitu, sebanyak 147 siswa $(36,21 \%)$ berada pada kategori sangat tinggi, 228 siswa $(56,16 \%)$ pada kategori tinggi, 27 siswa $(6,65 \%)$ kategori rendah, dan 4 siswa $(0,99 \%)$ pada kategori sangat rendah.

Hasil keseluruhan variabel lingkungan sekolah:

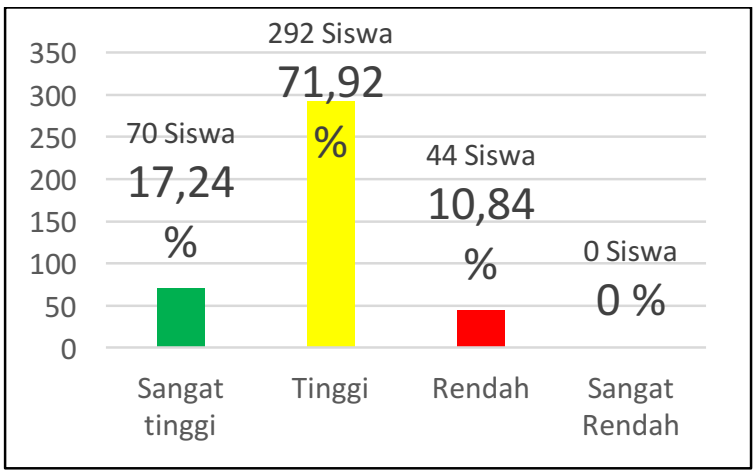

Gambar 13 Faktor Lingkungan Sekolah

Berdasarkan hasil penelitian pada Gambar 13 sebanyak 70 siswa (17,24\%) berada pada kategori sangat tinggi, 292 siswa $(71,92 \%)$ pada kategori tinggi, 44 siswa $(10,84 \%)$ kategori rendah, dan tidak ada siswa $(0 \%)$ pada kategori sangat rendah.. Hal ini menunjukkan faktor lingkungan sekolah berada pada kategori tinggi yakni 292 siswa (71,92\%) dengan persentase skor $74,62 \%$. 
Persentase skor masing-masing subvariabel dalam faktor lingkungan sekolah sebagai berikut: alumni sekolah sebesar $72,21 \%$ berada pada kategori tinggi, teman sebesar $71,18 \%$ pada kategori rendah, dan guru sebesar $78,27 \%$ pada kategori tinggi. Pada lingkungan sekolah subvariabel guru mempunyai persentase skor terbesar $(78,28 \%)$, untuk item yang mempunyai persentase terbesar terletak pada butir 43 sebesar $81,77 \%$ yang menyatakan bahwa "guru saya memberi gambaran bagaimana kersanya persaingan dunia kerja, hal itu membuat saya perlu menambah ilmu ke perguruan tinggi guna meningkatkan daya saing saya dalam dunia kerja". Sedangkan subvariabel teman mempunyai persentase skor terkecil $(71,18 \%)$, untuk item yang mempunyai rata-rata terkecil teletak pada butir 39 sebesar $66,87 \%$ yang menyatakan bahwa "teman-teman ingin melanjutkan ke perguruan tinggi membuat saya tertarik mengikuti mereka".

Lingkungan sekolah sangat mempengaruhi perkembangan pendidikan anak terutama untuk melanjutkan ke perguruan tinggi. Penelitian Shah (2012) [11] dalam jurnalnya mengungkapkan bahwa salah satu faktor yang mempengaruhi seseorang memilih pendidikannya di pendidikan tinggi adalah lingkungan pendidikannya (lingkungan sekolahnya). Pengaruh dari guru yang sangat besar dalam penelitian ini sesuai dengan pepatah bahasa jawa bahwa guru ialah "Digugu lan Ditiru" yang artinya bahwa perkataan guru haruslah didengarkan dan dipatuhi serta semua prilakunya pada kehidupan sehari-hari haruslah diikuti. Kemudian juga program bimbingan karir yang sesuai dengan pedoman khusus bimbingan konseling (Depdiknas, 2004:21) bahwa guru melakukan "pemantapan pemahaman diri berkenaan dengan kecenderungan karir yang hendak dipilih dan dikembangkan".

Berdasarkan hasil penelitian, dari faktor-faktor yang mempengaruhi minat masuk perguruan tinggi menunjukkan bahwa ternyata faktor dalam diri sendiri $(82,53 \%)$ mempunyai persentase skor yang lebih besar dibandingkan dengan faktor lingkungan keluarga $(79,85 \%)$ dan faktor lingkungan sekolah $(74,62 \%)$.
C. Pilihan Prodi Yang Sebidang

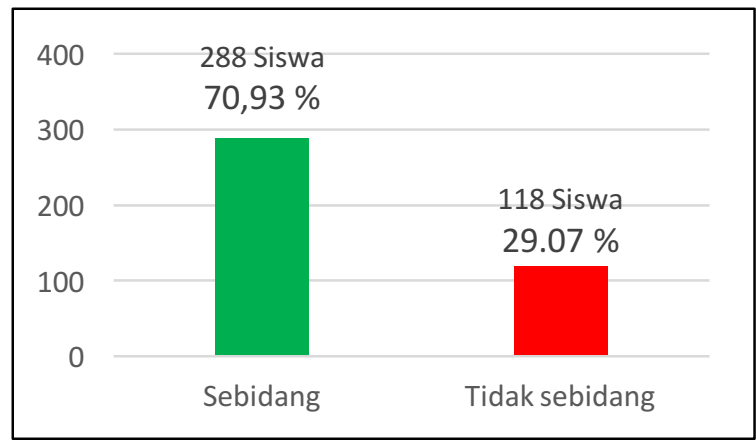

Gambar 14 Peminat Prodi yang Sebidang dan Tidak Sebidang

Gambar 14 menjelaskan jumlah peminat prodi pada perguruan tinggi. yang sesuai dengan bidang yang digelutinya yaitu 288 siswa (70,93\%), dan $118(29,06 \%)$ siswa memilih prodi lain yang tidak sebidang dari total 406 siswa. Hal ini menunjukkan bahwa sebagian besar peserta didik SMK Negeri prodi keahlian teknik komputer dan informatika Se-Kota Malang memilih untuk melanjutkan studi ke perguruan tinggi dengan prodi yang sesuai dengan bidang yang digelutinya (288 siswa $(70,93 \%)$ )

Berikut data peminat dari masingmasing prodi di perguruan tinggi yang sebidang dan tidak sebidang:

\section{Peminat Prodi Sebidang}

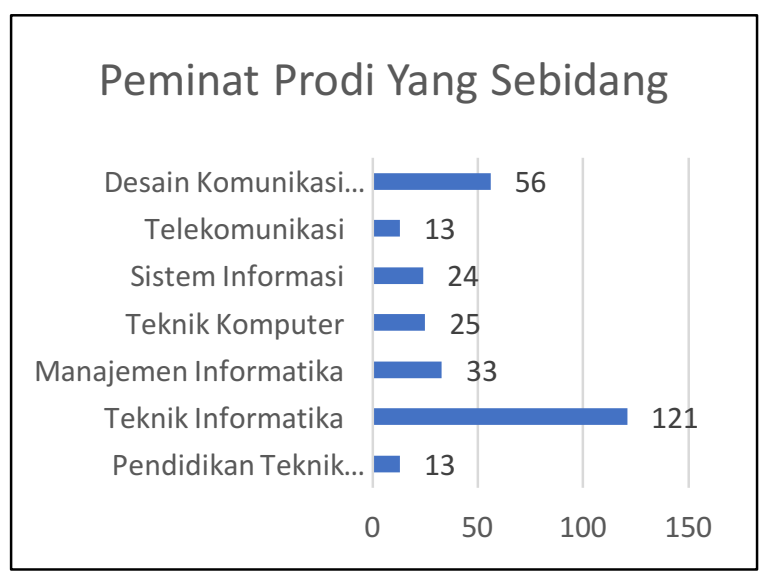

Gambar 15 Peminat Prodi Sebidang

Berdasarkan hasil penelitian pada Gambar 15 menjelaskan pilihan prodi sebidang yang paling banyak peminatnya adalah prodi teknik informatika sebanyak 121 siswa, kedua adalah desain komunikasi 
visual sebanyak 56 siswa, dan yang ketiga adalah manajemen informatika sebanyak 33 siswa.

\section{Peminat Prodi Tidak Sebidang}

Frekuensi peminat prodi pada perguruan tinggi yang tidak sebidang dengan jurusan yang digelutinya dapat dilihat pada Gambar 16. Terlihat prodi yang paling banyak diminati yang pertama adalah manajemen sebanyak 19 siswa, kedua hukum sebanyak 12 siswa dan yang ketiga adalah psikologi sebanyak 11 siswa.

Penelitian ini sesuai dengan data yang didapat dari badan statistik Universitas Negeri Malang bahwa peminat prodi teknik informatika mengalami peningkatan dalam 2 tahun terakhir. Kemudian untuk prodi pendidikan teknik informatika terus mengalami penurunan dalam 3 tahun terakhir, berdasarkan data penelitian peminat prodi pendidikan teknik informatika hanya 15 siswa.

Hasil pilihan prodi ini tentu dipengaruhi oleh faktor diri sendiri serta faktor lingkungan yang telah dipaparkan. Ryan (2010) [8] menunjukkan bahwa faktor dukungan keluarga dan teman - teman merupakan faktor yang signifikan dalam menentukan pilihan universitas. Orang tua berperan aktif untuk mengarahkan anaknya serta memberikan kebebasan untuk memilih prodi yang diinginkan. 


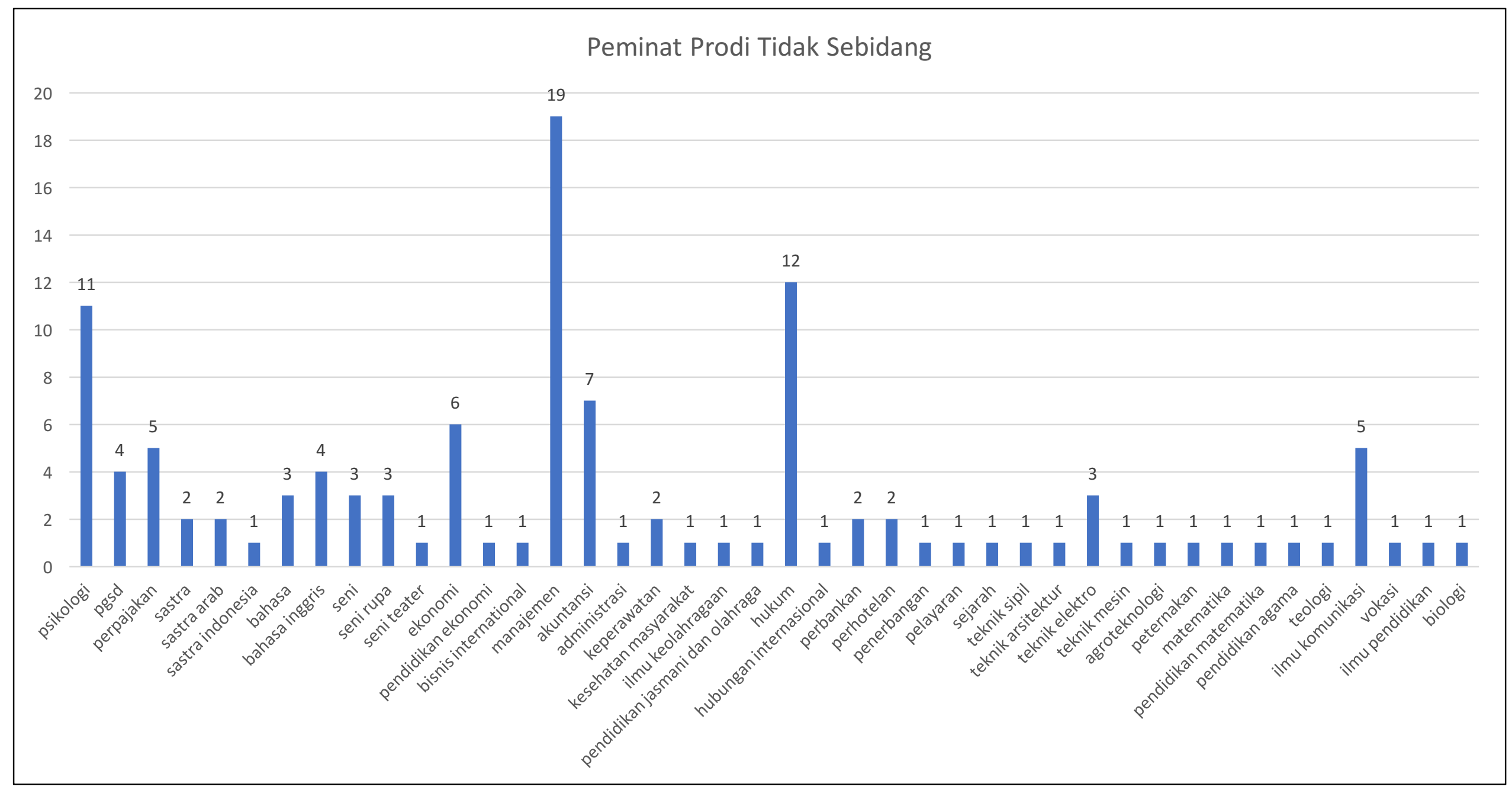

Gambar 16 Peminat Prodi Tidak Sebidang 


\section{SIMPULAN}

Hasil analisis yang telah dipaparkan menghasilkan kesimpulan yaitu:

Berdasarkan hasil analisis telah diketahui bahwa animo peserta didik SMK Negeri prodi keahlian teknik komputer dan informatika Se-Kota Malang untuk melanjutkan ke perguruan tinggi berada pada kategori tinggi sebesar 229 siswa $(56,40 \%)$ dengan persentase skor animo $79,85 \%$.

Berdasarkan hasil analisis dari faktor-faktor yang mempengaruhi minat masuk perguruan tinggi menunjukkan bahwa ternyata faktor dalam diri sendiri $(82,29 \%)$ mempunyai persentase skor yang lebih besar dibandingkan dengan faktor lingkungan keluarga $(79,67 \%)$ dan faktor lingkungan sekolah $(74,23 \%)$.

Animo peserta didik SMK Negeri prodi keahlian teknik komputer dan informatika Se-Kota Malang memilih untuk melanjutkan studi ke perguruan tinggi dengan prodi yang sesuai dengan bidang yang digelutinya (288 siswa $(70,93 \%)$ ) dan Prodi yang paling banyak diminati adalah Teknik informatika sebanyak 121 siswa.

\section{REFERENSI}

[1] Ajake, Uchenna Egodi. 2013. Family SocioEconomic Status and Delinquency among Senior Secondary School Students in Calabar South, Cross River State, Nigeria. American International Journal of Contemporary Research, 3(4), 83-88.

[2] Alfurqon, H.S. Minat Siswa SMK Melanjutkan Studi Ke Perguruan Tinggi Pada Siswa Kelas XII Jurusan Teknik Kendaraan Ringan SMK Negeri 2 Surakarta Tahun 2011/2012. Skripsi tidak diterbitkan, Surakarta: Fakultas Keguruan dan Ilmu Pendidikan Universitas Sebelas Maret.

[3] Dalyono, M. 1994. Psikologi Pendidikan. Jakarta: Rineka Cipta.

[4] Ihsan, F. 2003. Dasar-dasar Kependidikan. Jakarta: Rineka Cipta.

[5] Kainuwa, Ahmad. 2013. Influence of Socio-Economic and Educational
Background of Parents on their Children's Educational in Nigeria. International Journal of Scientific and Research Publications, 3(10), 1-8.

[6] Krapp, A. 2007. An EducationalPsychological Conceptualisation of Interest. Journal of Commerce Study, $7(1), 5-21$.

[7] Lea, Susan J dkk. 2003. Higher Education Students' Attitudes to Student-centred Learning: beyond 'educational bulimia'?. Studies in higher education, 28(3), 321-334.

[8] Ryan, Yano. 2010. Factors Influencing the Choice of College Among Undergraduate Students in Public Universities in Kenya. A Case Study of the University of Eldoret. Australian Journal of Commerce Study.

[9] Sardiman. 2011. Interaksi dan Motivasi Belajar Mengajar. Jakarta: PT. Raja Grafindo Persada.

[10] Suciani, Y \& Setyadin, B. 2008. Analisis Animo Siswa SD/MI dalam Partisipasi Memilih SLTP di SD/MI seKota Blitar. Jurnal IImu Pendidikan Volume 21 (1): 51-58.

[11] Shah, Mahsood. 2013. Factors Influencing Student Choice to Study at Private Higher Education Institutions. Quality Assurance in Education, 21(4), 402-416.

[12] Suhirno. 2011. Minat Masuk Perguruan Tinggi Bagi Siswa Kelas Xii Program Keahlian Teknik Ototronik Di Smk Negeri 1 Seyegan. Skripsi tidak diterbitkan. Yogyakarta: Fakultas Teknik Universitas Negeri Yogyakarta.

[13] Suprapto. 2007. Minat Masuk Perguruan Tinggi Bagi Siswa Kelas lii Program Keahlian Teknik Instalasi Listrik Pada Smk Di Purworejo. Laporan penelitian UNNES.

[14] Syah, M. 2005. Psikologi Pendidikan Suatu Pendekatan Baru. Bandung: Remaja Rosdakarya

[15] Wahyudi, T. 2006. Minat dan Motivasi siswa kelas 1 SMA Muhammadiyah2 Cepu Kabupaten Blora Dalam Mengikuti Kegiatan Ekstrakurikuler Olahraga Bolavoli Tahun 2006 
ISSN 2089-8673 (Print) | ISSN 2548-4265 (Online)

Volume 8, Nomor 2, Juli 2019

(Skripsi). Semarang : PJKR. FIK. UNNES.

just the people': the role of social support in the first-year experience of

[16] Wilcox, Paula dkk. 2005. It was higher education. Studies in Higher nothing to do with the university, it was

Education, 30(6). 707-722. 